\title{
Anaerobically digested dairy fiber in soilless potting media for poinsettias
}

\author{
John R. Lamont ${ }^{1} \cdot$ George C. Elliott $^{1}$
}

Received: 4 February 2016/Accepted: 11 May 2016/Published online: 18 May 2016

(c) The Author(s) 2016. This article is published with open access at Springerlink.com

\begin{abstract}
Purpose Sphagnum peat moss has been a primary component of soilless potting media for decades. Concerns over the sustainability of harvesting peat have fostered a search for renewable media components. Anaerobically digested dairy fiber (ADDF), a by-product of methane production, shows promise as an alternative to peat.

Methods Poinsettias (Euphorbia pulcherrima 'Classic Red') were grown in media containing peat-perlite in a 4:1 ratio or peat-ADDF-perlite in a 2:2:1 ratio. Bulk density, container capacity, water-holding capacity, $\mathrm{pH}$ and $\mathrm{EC}$ of both mixes were evaluated before planting. Shoot height, shoot fresh weight, shoot dry weight and leaf tissue nutrient concentrations of plants were measured at commercial maturity. PourThru samples were taken from pots regularly to evaluate phosphate leaching potential from ADDF.

Results There were no differences in physiochemical properties between mixes. Poinsettias grown in the peatADDF-perlite were significantly taller and had greater shoot fresh weight, shoot dry weight and leaf tissue N, P, $\mathrm{Mn}, \mathrm{Na}$ and $\mathrm{Zn}$ concentrations than control plants. PourThru samples from pots containing peat-ADDF-perlite had greater phosphate concentrations than peat-perlite for approximately 5 weeks.

Conclusions The ADDF used in this trial can be used as a $50 \%$ substitute for peat in potting media for poinsettias and contains significant amounts of plant available nutrients. Additional nutrients supplied by ADDF should be carefully managed as they can contribute to plant growth or
\end{abstract}

John R. Lamont

john.lamont@mail.mcgill.ca

1 Department of Plant Science, University of Connecticut, 1376 Storrs Rd., Unit 4067, Storrs, CT 06269, USA leaching pollution. Using ADDF in media could provide growers with a local, renewable substitute for peat and provide supplemental income to dairy farmer.

Keywords Peat $\cdot$ Euphorbia pulcherrima $\cdot$ Substrate . Floriculture $\cdot$ Nutrient leaching

\section{Introduction}

Poinsettias (Euphorbia pulcherrima) have been the most important potted flowering crop in North America for several decades and account for a significant market share of potted flowering plants in Europe and Australia (Dole and Wilkins 1999). Despite its popularity, a recent decline in poinsettia sales has necessitated growers to develop innovative ways to differentiate their product and increase profits (Lopez and Camberato 2011). Consumers have indicated they are more likely to purchase and willing to spend up to $15 \%$ more on sustainably produced poinsettias (Lopez et al. 2009). One way to increase perceived sustainability of poinsettia production is using recycled agricultural waste as a partial or complete substitute for peat in potting media.

Using agricultural wastes as peat substitute can benefit the waste producers, growers and the environment. Agricultural waste producers can transform the liability of waste disposal into a source of income by marketing their waste as a valuable horticultural product (Raviv 2005). Local agricultural wastes are generally less expensive for growers than peat (Raviv 2005; Restrepo et al. 2013), which is produced in cold, northern regions and must be shipped long distances to more temperate horticultural areas (Roberston 1993). Growers who use agricultural wastes as peat substitutes can market their plants as 
sustainable and command a higher price. Replacing peat with agricultural wastes is environmentally sound because nutrients from wastes can be recycled into plant growth thus reducing fertilizer needs and environmental impacts of peat production can be reduced by reducing the demand for peat.

Several agricultural wastes have been successfully used in poinsettia potting media, including vericomposted manure (Hidalgo and Harkess 2002), pine tree substrate (Jackson et al. 2008), and composted cotton burrs (Wang and Blessington 1990). Replacing peat with composted olive mill waste reduced media porosity and yielded poinsettias of inferior size and quality to those grown in a peat-perlite medium (Papafotiou et al. 2004). The best peat substitutes have physiochemical properties that are similar to peat.

Anaerobically digested dairy fiber (ADDF), a by-product of methane extraction from dairy manure, has shown potential as a partial peat substitute in potting media for bedding plants (MacConnell and Collins 2007; Lamont 2015). Methane production can generate some income (Sorathiya et al. 2014), however, marketing ADDF as a horticultural material could become a source of additional income for dairy farmers and provide a solution to some nutrient and waste management problems associated with raw manure (Miller and Moyle 2014). Nutrient leaching from accumulated manure is a significant source of nonpoint source water pollution. If ADDF were used in growing media, nutrients that would otherwise be lost as pollutants could be used for plant nutrition (Alburquerque et al. 2012). Additionally, creating a lucrative market for ADDF can incentivize small dairy farmers, for whom anaerobic digestion would otherwise not be economically viable (Klavon et al. 2013), to adopt environmentally sound anaerobic digestion units for waste treatment (Miller and Moyle 2014).

Although studies have tested aerobically composted manure as a peat substitute in media for growing foliage plants ( $\mathrm{Li}$ et al. 2009), nursery plants (Shober et al. 2011), and bedding plants (Shober et al. 2010), little work has been done using anaerobically digested dairy fiber as a media component. MacConnell and Collins (2007) found that media with ADDF as a complete substitute for peat had porosity and water-holding capacity similar to that of a peat-based mix. Petunias and violets were grown successfully in this ADDF-containing mix, but the plants had stunted root systems compared to plants grown in a control mix, likely due to an inadequate supply of Ca. Generally, limestone is used to supply peat-based media with $\mathrm{Ca}$ and raise $\mathrm{pH}$. Since ADDF is alkaline in reaction, an alternative $\mathrm{Ca}$ source, such as gypsum, must be used.
We tested a variety of floriculture crops, including geranium, petunia, viola, chrysanthemum and cyclamen, in various media blends containing combinations ADDF, peat, coir, perlite and parboiled rice hulls. Results varied among crops and media blends, but a mix with a 2:2:1 ratio of peat-ADDF-perlite consistently yielded plants of equal or greater size and quality to those grown in the peat-based control mix (Lamont 2015).

The objectives of this research were to evaluate ADDF as a partial substitute for peat in potting media for poinsettias and to evaluate nutrient availability in an ADDFcontaining mix.

\section{Methods}

Anaerobically digested dairy fiber was obtained from a local plug flow anaerobic digestion unit (Freund Farm, East Canaan, CT, USA). Manure from a herd of $\sim 350$ dairy cows were fed into the digester with a hydraulic reaction time of 20 days at $35^{\circ} \mathrm{C}$, resulting in a slurry with 11-13\% total solids (Klavon 2011), which was further processed using proprietary methods. The separated solids constituted the ADDF used in this project.

Media used in the experiment were peat-perlite in a 4:1 ratio with $2.5 \mathrm{~g} \mathrm{~L}^{-1}$ dolomitic lime and peat-ADDF-perlite in a 2:2:1 ratio with $4 \mathrm{~g} \mathrm{~L}^{-1}$ gypsum. Physical properties of the mixes including bulk density, container capacity, and water-holding capacity were evaluated before planting using the techniques described by Elliott (1992). Saturated media extracts (Warnke 2011) were taken to estimate media $\mathrm{pH}$ and electrical conductivity using Cardy Twin $\mathrm{pH}$ and conductivity meters (Horiba Corp., Kyoto, Japan).

Rooted cuttings of poinsettia (Euphorbia pulcherrima 'Classic Red') were transplanted into 6" jumbo azalea pots $(1.8 \mathrm{~L})$ containing the peat-perlite and peat-ADDF-perlite mixes previously described with fifteen plants in each media treatment. Poinsettias were grown in a computer controlled corrugated polycarbonate greenhouse with $24{ }^{\circ} \mathrm{C}$ day and $20{ }^{\circ} \mathrm{C}$ night set points. Pots were placed in flood and drain trays and irrigated with $100 \mathrm{mg} \mathrm{L}^{-1} \mathrm{~N}$ from Plantex $19 \mathrm{~N}$ $0.9 \mathrm{P}-15.8 \mathrm{~K}$. Plants were pinched 3 weeks after transplanting. Plants received day lengthening supplemental lighting for 6 weeks after transplanting after which, flowering was initiated with short days. At commercial maturity 15 weeks post-transplant, plant growth was evaluated qualitatively based on appearance; and quantitatively by measuring shoot height, shoot fresh weight, shoot dry weight and leaf tissue concentration of $\mathrm{N}, \mathrm{P}, \mathrm{K}, \mathrm{Ca}, \mathrm{Mg}, \mathrm{Al}, \mathrm{B}, \mathrm{Cu}, \mathrm{Fe}, \mathrm{Mn}, \mathrm{Mo}, \mathrm{Na}$ and Zn. PourThru samples (Wright 1986) were taken approximately biweekly and analyzed for phosphate concentration colorimetric (Murphy and Riley 1962). 


\section{Statistical analysis}

A statistical analysis system mixed procedure (SAS Institute Inc., Cary, NC) was used to analyze all data. Tukey's honestly significant difference (HSD) test was used to find differences in treatment means at $P \leq 0.05$.

\section{Results and discussion}

The ADDF evaluated in this trial was an acceptable substitute for $50 \%$ of the peat in growing media for poinsettias (Fig. 1). There were no significant differences in physical properties or $\mathrm{pH}$ between the two media (Table 1) and the physical properties and $\mathrm{pH}$ of both mixes fall within the recommended ranges for growing media. The peat-ADDF-perlite mix had a significantly greater EC than the peat-perlite mix (Table 1). The initial EC of peat-ADDF-perlite is considered high (Dole and Wilkins 1999) but was found to be a result of plant available nutrients rather than phytotoxic elements, such as Na (Table 3).

Plants grown in the peat-ADDF-perlite mix were significantly taller and had greater fresh and dry shoot mass than control plants (Table 2). Poinsettias grown in the peatADDF-perlite mix also had greater leaf tissue concentrations of N, P, Mn, Na and $\mathrm{Zn}$ (Table 3). The plants grown in the peat-perlite mix had greater leaf tissue concentrations of $\mathrm{Ca}$ and $\mathrm{K}$ (Table 3); however, plants grown in both mixes had $\mathrm{Ca}$ tissue concentrations that met or exceeded the critical level ( $0.5 \%$ of dry weight) for poinsettias (Dole and Wilkins 1999). Leaf tissue $P$ and $\mathrm{Zn}$ concentrations for plants grown in peat-perlite were below the recommended ranges for poinsettias (Dole and Wilkins 1999).

PourThru samples from pots containing peat-ADDFperlite had greater phosphate-P concentrations than those of the control plants for approximately 5 weeks (Fig. 2). The continued release of $\mathrm{P}$ may be from the dissolution of calcium phosphate minerals, which are often found in dairy manure and dissolve at $\mathrm{pH}$ below 7 (Shober et al. 2010).

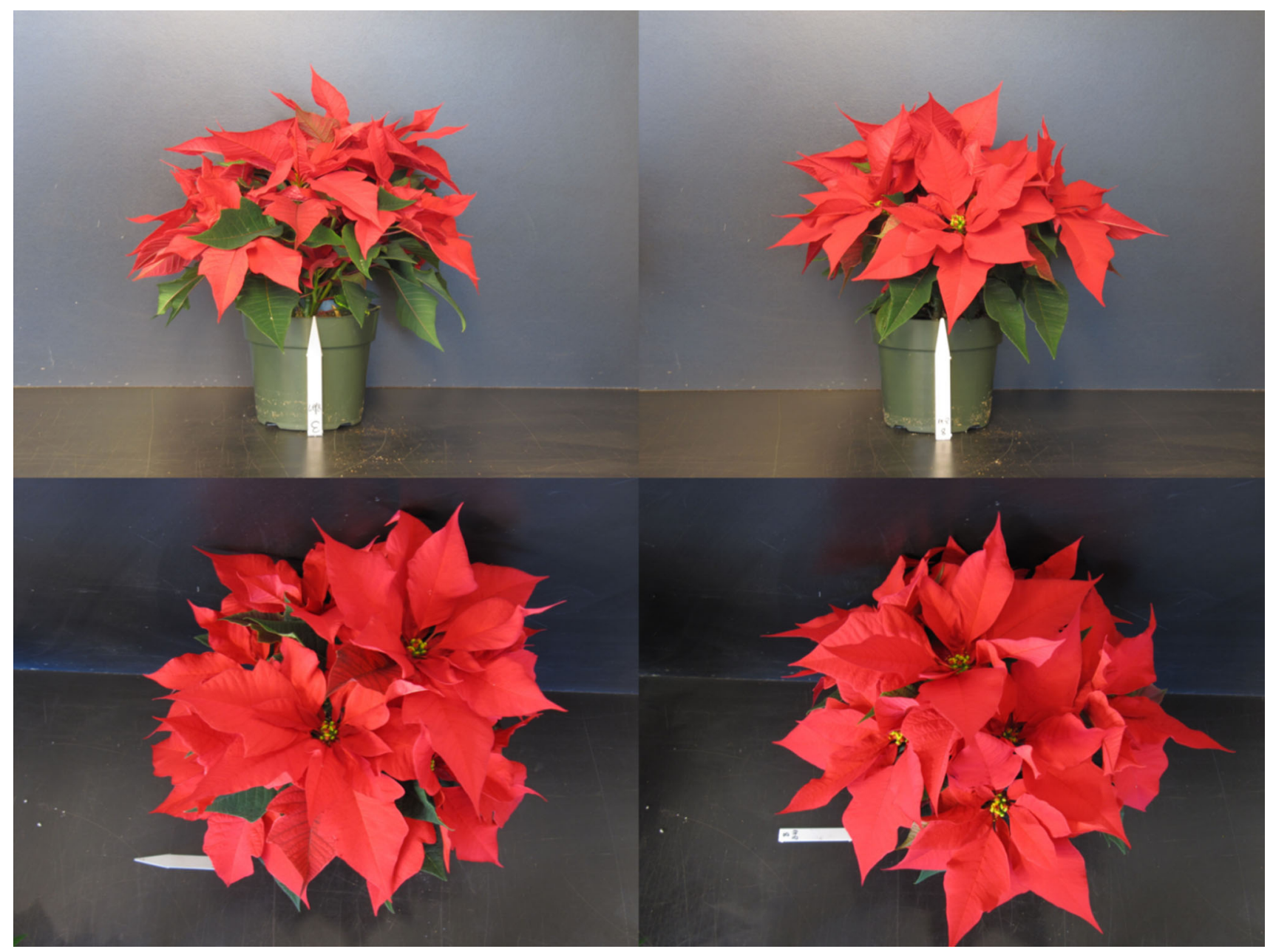

Fig. 1 Poinsettias grown in peat-ADDF-perlite (left) or peat-perlite (right) 
Table 1 Mean effective water-holding capacity (EWHC), container capacity (CCAP), dry bulk density $\left(D_{\mathrm{b}}\right)$, total porosity, $\mathrm{pH}$ and EC of $4: 1$ peat-perlite and 2:2:1 peat-ADDF-perlite mixes

\begin{tabular}{lllllll}
\hline Mix & EWHC, \% volume & CCAP, \% volume & $D_{\mathrm{b}}, \mathrm{g} / \mathrm{cm}^{3}$ & Total porosity, \% volume & $\mathrm{pH}^{*}$ & $\mathrm{EC}^{*}, \mathrm{~ms} \mathrm{~cm}^{-1}$ \\
\hline Peat-Perlite & 52.7 & 58.7 & 0.106 & 84 & 5.53 & 0.98 \\
Peat-ADDF-Perlite & 52.6 & 61.2 & 0.116 & 88 & 5.63 & 3.30 \\
\hline
\end{tabular}

Parameters with a asterisk are significantly different based on $P$ value $\leq 0.05$

Table 2 Mean fresh weight, dry weight and height of poinsettias grown in peat-perlite or peat-ADDF-perlite media

\begin{tabular}{llll}
\hline Mix & Fresh weight*, g & Dry weight*, & Height*, mm \\
\hline Peat-perlite & 117 & 15.5 & 177 \\
ADDF-peat-perlite & 133 & 18.0 & 192 \\
\hline
\end{tabular}

Parameters with a asterisk are significantly different based on $P$ value $\leq 0.05$

Table 3 Mean dried leaf tissue nutrient concentrations of poinsettia grown in two greenhouse media

\begin{tabular}{llllllllllllll}
\hline & $\mathrm{N}^{*}$ & $\mathrm{P}^{*}$ & $\mathrm{~K} *$ & $\mathrm{Ca} *$ & $\mathrm{Mg}$ & $\mathrm{Al}$ & $\mathrm{B}$ & $\mathrm{Cu}$ & $\mathrm{Fe}$ & $\mathrm{Mn} *$ & $\mathrm{Mo}$ & $\mathrm{Na} *$ & $\mathrm{Zn}{ }^{*}$ \\
\hline Mix & $\%$ & $\%$ & $\%$ & $\%$ & $\%$ & $\mathrm{mg} / \mathrm{kg}$ & $\mathrm{mg} / \mathrm{kg}$ & $\mathrm{mg} / \mathrm{kg}$ & $\mathrm{mg} / \mathrm{kg}$ & $\mathrm{mg} / \mathrm{kg}$ & $\mathrm{mg} / \mathrm{kg}$ & $\%$ & $\mathrm{mg} / \mathrm{kg}$ \\
Peat-perlite & 3.5 & 0.27 & 2.5 & 0.6 & 0.5 & 4.4 & 26.7 & 10.6 & 217.9 & 81.9 & 0.1 & 0.2 & 50.8 \\
ADDF-peat-perlite & 3.9 & 0.34 & 2.3 & 0.5 & 0.5 & 1.1 & 26.7 & 12.2 & 140.8 & 108.1 & 0.0 & 0.3 & 86.2 \\
\hline
\end{tabular}

Nutrients with asterisk have significantly concentrations different means between plants grown in the two mixes at $P$ value $\leq 0.05$

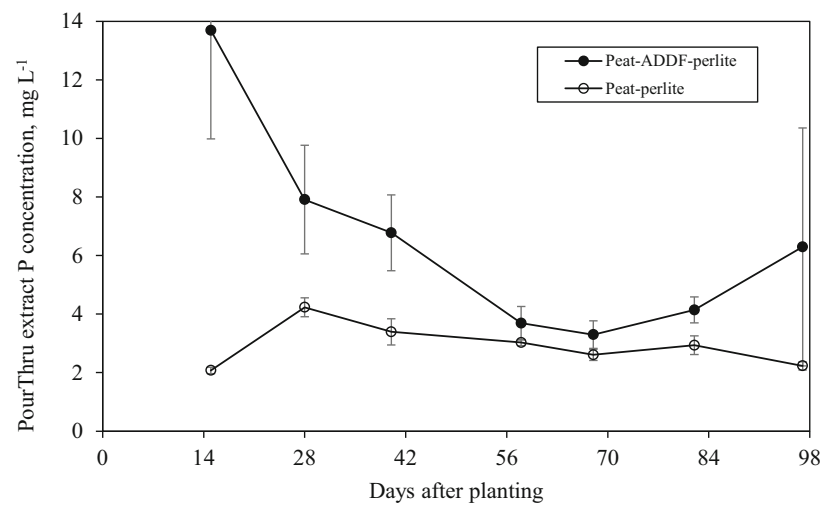

Fig. 2 Mean phosphorus concentration in PourThru extracts over time from poinsettia crop grown in peat-perlite and peat-ADDFperlite media

Earlier trials indicated ADDF contains significant amounts of plant available P (Lamont 2015). In this trial, plants were fertilized at a low rate to accentuate any gains from additional nutrients from ADDF. Tissue analysis results of this trial show that ADDF not only supplies plant available $\mathrm{P}$, but also $\mathrm{N}, \mathrm{P}, \mathrm{K}, \mathrm{Mn}$ and $\mathrm{Zn}$. Plants grown in peat-ADDF-perlite clearly benefited from the additional nutrients supplied by ADDF.

The additional nutrients supplied by ADDF could contribute to water pollution so measures should be taken to limit nutrient leaching, such as using irrigation systems with little or no leaching, adjusting fertilization regimes or formulating mixes that limit nutrient leaching. Certain media amendments, such as dried alum sludge (Bugbee and Elliott 1999), clay, and bark (Bugbee and Elliott 1998) have been shown to reduce nutrient leaching from media containing nutrient-rich organic components without adversely effecting plant growth.

While this trial yielded a positive growth response, it is only representative of ADDF from one anaerobic digester and one dairy farm. Dairy feed can vary from region to region and seasonally, so the feedstock used to produce ADDF likely varies equally. Regional variability in dairy manure may have contributed to discrepancies between the results of this research and the results of research using a composted dairy manure product in Florida (Shober et al. 2011). However, similarities in the results of chemical and physical analysis of ADDF and ADDF-containing mixes between MacConnell and Collins (2007) in Washington and this trial in Connecticut demonstrate that ADDF can be consistent from region to region and farm to farm. Differences in climate have been shown to influence the nutrient availability in manure. Growing degree days have been shown to be useful in predicting nitrogen availability from manure (Griffin and Honeycutt 2000). Special consideration must be given to any potential variability in ADDF. While the scope of this trial was limited to one crop, when results from this trial are combined with the results of our previous trials using ADDF in media for other floriculture crops (Lamont 2015), ADDF is shown to be a promising substitute for peat for a diversity of crops. 
As with other alternative media components, more research is needed to establish the best ways to manage ADDF in media and to process ADDF into a consistent horticultural material. Apart from establishing best practices, the ADDF evaluated in this trial it is an acceptable substitute for peat in media for poinsettias.

Author contribution statement JL was involved in all aspects of the design, execution, analysis and interpretation of this project. GE was the principle investigator and supervisor of this project and was involved in all aspects of the design and interpretation of this project.

Acknowledgments We thank Freund Farm for supplying the anaerobically digested dairy fiber used in this project, Max Pianka for data collection and chemical analyses and Dawn Pettinelli at the University of Connecticut Soil Testing Lab for additional analysis. We also thank the USDA Hatch Project (CONS00879) and the Cooperative Development Institute for funding this project.

Open Access This article is distributed under the terms of the Creative Commons Attribution 4.0 International License (http://crea tivecommons.org/licenses/by/4.0/), which permits unrestricted use, distribution, and reproduction in any medium, provided you give appropriate credit to the original author(s) and the source, provide a link to the Creative Commons license, and indicate if changes were made.

\section{References}

Alburquerque JA, de la Fuente C, Ferrer-Costa A, Carrasco L, Cegarra J, Abad M, Bernal MP (2012) Assessment of the fertiliser potential of digestates from farm and agroindustrial residues. Biomass Bioenerg 40:181-189. doi:10.1016/j.biom bioe.2012.02.018

Bugbee GJ, Elliott GC (1998) Leaching of nitrogen and phosphorus from potting media containing biosolids compost as affected by organic and clay amendments. B Environ Contam Tox 60:716-723. doi:10.1007/s001289900685

Bugbee GJ, Elliott GC (1999) Effects of sucrose and dried alum sludge on the growth of Rudbeckia and leaching of nitrogen and phosphorus from potting media containing biosolids compost. B Environ Contam Tox 63:766-773. doi:10.1007/s001289901045

Dole JM, Wilkins HF (1999) Floriculture principles and species. Prentice Hall, Upper Saddle River

Elliott GC (1992) Imbibition of water by rockwool-peat container media amended with hydrophilic gel or wetting agent. J Am Soc Hortic Sci 117(5):757-761

Griffin TS, Honeycutt CW (2000) Using growing degree days to predict nitrogen availability from livestock manure. Soil Sci Soc Am J 64(5):1876-1882. doi:10.2136/sssaj2000.6451876x

Hidalgo PR, Harkess RL (2002) Earthworm castings as a substrate amendment for chrysanthemum production. Hort Sci 37(7):1035-1039

Jackson BE, Wright RD, Barnes MC (2008) Pine tree substrate, nitrogen rate, particle size, and peat amendment affect poinsettia growth and substrate physical properties. Hort Sci 43(7):2155-2161

Klavon, KH (2011) Design and economics of plug-flow, small-scale anaerobic digesters for temperate climates. Dissertation, University of Maryland
Klavon KH, Lansing SA, Mulbry W, Moss AR, Felton G (2013) Economic analysis of small-scale agricultural digesters in the United States. Biomass Bioenerg 54:36-45. doi:10.1016/j. biombioe.2013.03.009

Lamont JR (2015) Evaluating anaerobically digested dairy fiber as a substitute for peat in container production and nutrient availability from organic fertilizers and amendments. Master's Theses, University of Connecticut

Li Q, Chen J, Caldwell RD, Deng M (2009) Cowpeat as a substitute for peat in container substrates for foliage plant propagation. Hort Technol 19(2):340-345

Lopez RG, Camberato DM (2011) Growth and development of 'Eckespoint Classic Red' poinsettia in biodegradable and compostable containers. Hort Technol 21(4):419-423

Lopez RG, Dennis J, Behe BK (2009) Consumer perceptions of sustainably produced poinsettias. Greenhouse Grower 27:60-64

MacConnell CB, Collins HP (2007) Utilization of re-processed anaerobically digested fiber from dairy manure as a container media substrate. Acta Hortic 819:286-297. doi:10.17660/Acta Hortic.2009.819.32

Miller J, Moyle J (2014) Manure as a natural resource: alternative management opportunities. Univ Md Extension Bull EB-420. doi:10.13016/M2GD04

Murphy J, Riley JP (1962) A modified single solution method for the determination of phosphate in natural waters. Anal Chim Acta 27:31-36. doi:10.1016/S0003-2670(00)88444-5

Papafotiou M, Phsyhalou M, Kargas G, Chatzipavlidis I, Chronopoulos J (2004) Olive-mill wastes compost as growing medium component for the production of poinsettia. Sci Hortic-Amst 102(2):167-175. doi:10.1016/j.scienta.2003.11.016

Raviv M (2005) Production of high-quality composts for horticultural purposes: a mini-review. Hort Technol 15(1):52-57

Restrepo AP, García JG, Moral R, Vidal F, Pérez-Murcia MD, Bustamante MÁ, Paredes C (2013) A comparative cost analysis for using compost derived from anaerobic digestion as a peat substitute in a commercial plant nursery. Cienc Investig Agrar 40(2):253-264. doi:10.4067/S0718-16202013000200002

Roberston RA (1993) Peat, horticulture and environment. Biodivers Conserv 2:541-547. doi:10.1007/BF00056747

Shober AL, Wiese C, Denny GC, Stanley CD, Harbaugh BK, Chen J (2010) Plant performance and nutrient losses during containerized bedding plant production using composted dairy manure solids as a peat substitute in substrate. Hort Sci 45(10): 1516-1521

Shober AL, Wiese C, Denny GC, Stanley CD, Harbaugh BK (2011) Plant performance and nutrient losses during containerized landscape shrub production using composted dairy manure solids as a peat substitute in substrate. Hort Technol 21(2):240-245

Sorathiya LM, Fulsoundar AB, Tyagi KK, Patel MD, Singh RR (2014) Eco-friendly and modern methods of livestock waste recycling for enhancing farm profitability. Int J Recycl Organ Waste Agric 3(1):1-7. doi:10.1007/s40093-014-0050-6

Wang YT, Blessington TM (1990) Growth and interior performance of poinsettia in media containing composted cotton burrs. Hort Sci 25(4):407-408

Warnke D (2011) Recommended test procedures for greenhouse growth media. In: Northeast Coordinating Committee for Soil Testing (ed) Recommended soil testing procedures for the northeastern United States 3rd edn. Northeastern Regional Publication No. 493, pp 103-110

Wright RD (1986) The pour-through nutrient extraction procedure. Hort Sci 21:225 